\title{
Analysis of the Application of Modern Apprenticeship in English Teaching of Preschool Education Major in Higher Vocational Colleges
}

\author{
Xinbei Wang \\ Qingdao Technical College \\ Shandong Province, Qingdao, 266555, China
}

\begin{abstract}
The main purpose of setting up the preschool education major is to provide professional educational technology talents for society, which plays an important role in training of the next generation of society. Besides, with the popularization of English in China, the requirements for English teaching have gradually increased. However, the traditional te aching mode of preschool education major in higher vocational colleges has many disadvantages, which leads to the serious decline of teaching quality. As a result, students can't learn well and are difficult to adapt to the needs of society. Based on the analysis of modern apprenticeship, this paper explores how to improve the English teaching level of preschool education major in higher vocational colleges to the greatest extent.
\end{abstract}

Keywords-Modern apprenticeship; Preschool education major in higher vocational colleges; English teaching

\section{INTRODUCTION}

Scholars in the domestic education sector have conducted in-depth analysis on modern apprenticeship, mainly including two aspects. First, on the basis of explaining the theory and practice of modern apprenticeship, it focuses on clarifying the role of apprenticeship in domestic higher vocational education. Second, it clarifies the role and achievements of modern apprenticeship in different discipline categories. In the English teaching of preschool education major in our country, the traditional education management mode has serious drawbacks. The introduction of modern apprenticeship can improve the preschool education in higher vocational colleges to the great extent, especially in English teaching.

\section{The Connotation of Modern ApPrenticeship}

\section{A. The Definition of Modern Apprenticeship.}

In general, the educational circle defined modern apprenticeship as the introduction of modern educational methods under the traditional apprenticeship model to promote the deepest cooperation between schools and employment enterprises [1]. In this teaching mode, the principal role of the students is fully played, and the teachers play a role of assisting and guiding, so the enthusiasm of students is fully aroused. In addition, In the English teaching of preschool education major in higher vocational colleges, apprenticeship can strengthen students' understanding and application ability, give them more practical opportunities and improve their spoken English. This also requires teachers to know students' learning characteristics and keep an equal relationship with students in teaching.

\section{B. Features of Modern Apprenticeship}

The most basic factor in modern apprenticeship is the establishment and stability of mentoring relationship, which guarantees the improvement of students' practical ability. At the same time, another important factor is the cooperation between schools and enterprises, which proposed to make up for the lack of professional and technical talents in society. Therefore, modern apprenticeship is based on the mentoring relationship between teachers and students, with the cooperation between schools and enterprises as the link and cultivating professional technical talents as the purpose [2]. These three links are indispensable for this modern educational management mode.

\section{Targeted Group of Modern Apprenticeship}

In the public's impression, the traditional apprenticeship has low requirements on knowledge and ability, which greatly leads to the decline of the development of the traditional apprenticeship. However, with the development of modern apprenticeship in China, it is seen that the implementation of modern apprenticeship in higher vocational colleges has not only promoted the students' practical ability, but also satisfied society's needs for technical talents to a large extent, which is especially evident in the second and the third industry. At present, the apprenticeship mode of school-enterprise cooperation has provided many employees with excellent knowledge and ability for enterprises, and its targeted group has also expanded form general rural children to the majority of middle and higher vocational personnel.

\section{Modern Apprenticeship Has Clearly Put Forward the Cooperation Mode Between Schools and Enterprises}

Although the traditional apprenticeship is prominent in cultivating professional skills, it has serious drawbacks. For example, the traditional apprenticeship has strong dependence on masters, but attaches less importance to the theoretical knowledge, which leads to the low educational efficiency and even some inequality. Besides, the theoretical knowledge ignored by the traditional apprenticeship is precisely the current society needs for talents. While as for the modern apprenticeship, the systematical study of theoretical knowledge is attached same importance as to the practical experience 
learning under the guidance of masters. The combination of theoretical knowledge and practical ability is truly realized, and the English teaching of preschool education major in higher vocational colleges make full use of masters and enterprises via modern apprenticeship.

\section{E. Modern Apprenticeship}

Traditional apprenticeship, clarifying more training system with the company and less learning and narrow scope of knowledge, is difficult to adapt to the development of society. Compared with it, modern apprenticeship takes the relevant content teaching and standards as core, and uses them as evaluation standards, so the scope of teaching content is expanded, the cultivation of practical ability is strengthened, and students' learning enthusiasm is greatly aroused. Compared with traditional apprenticeship, which only aims at a certain craft or skill training, modern apprenticeship has made great progress both in quality and breadth, which also gives students more freedom of choice.

III. The Present Situation And Existing Problems in English TeAching of Preschool Education Major IN Higher Vocational EDUCATION UNDER MODERN APPRENTICESHIP

\section{A. The Present Situation}

1) Teaching Standards of Higher Vocational Colleges are not Practical

English is one of the key courses of preschool education major in each higher vocational college. However, the basic requirement of modern apprenticeship is that enterprises participate in management, which means that schools should formulate teaching plans with the participation of enterprises. To a certain extent, it will make the formulation of teaching targets unreasonable. Especially in most of the teaching plans, part of time during the first year students are arranged to receive professional knowledge in school, other time to conduct social practice in enterprises. In this way schools are difficult to complete teaching task and to give students good education of theoretical knowledge. Besides, schools and enterprises tend to be more inclined to the needs of enterprises in the formulation of teaching objectives, which makes the students' theoretical knowledge less stable. In the long run, students' short board will affect the efficiency of the enterprise and cannot meet the needs of society.

2) Some Students in the Modern Apprenticeship System Have Some Vague Cognition in Their Identities

The school-enterprise cooperation mode of modern apprenticeship has led some students to be confused about self-positioning. The main purpose of enterprises to cooperate with schools is to get fresh blood. However, when students do internships, they often have a vague understanding of their own identity, and they do not have full recognition of their own development and future direction [3]. When they participate in internships, they often regard themselves as students and the internship in enterprises just taken as learning requirements of school. Those students appear to be lazy. Compared with learning through hard work, they pursue leisure jobs blindly, which is against the original intention of taking skills training, and will bring about great problems to their development in the long run.

\section{3) The Learning Environment is Poor}

The good learning environment is essential for students, but for some English students doing internship in enterprises, they have poor foundation and poor learning environment to improve them, cannot satisfy the needs for talents of society.

\section{B. The Existing Problems}

1) The Mode of Training Talents of Schools is Relatively Simple

In the current apprenticeship teaching activities, the students' reliance on related enterprises is strong, which makes the school more biased towards enterprises in various aspects such as curriculum setting, and pays too much attention to the relevant skills training of the students, while ignoring the students' cultural courses setting, which has negative impact on students' ability improvement [4]. This teaching mode will limit students' theoretical knowledge learning. Therefore, in the daily teaching activities of the school, more attention should be paid to the comprehensive quality training of the students. At the same time of training students' professional skills, schools are supposed to have higher requirements on students' comprehensive quality and knowledge breadth to meet the needs for talents of society.

2) The English Teaching of Preschool Education Major in Higher Vocational Colleges are Lack of Practice

At present, most of the students majoring in pre-school education of English major are directly engaged in English education in the educational field after graduation. Most of the students are only engaged in ordinary teaching internships in relevant educational institutions. Most of them have no relevant experience in English teaching, lack of English teaching experience and English teaching methods. How to successfully lead students to learn English effectively in preschool education English education, most of them have no experience, lack of education methods. That is to say, at present, preschool educators engaged in English education mostly lack the corresponding practical work ability and cannot perfectly integrate theoretical knowledge and practice. As a result, the learning content of students is totally based on textbook and is not practical. Students' learning enthusiasm and learning efficiency are depressed to the great extent. Introducing modern apprenticeship to class is an effective way to improve this situation.

\section{The Application of Modern Apprenticeship in the English Teaching of Preschool Education Major in Higher Vocational Colleges}

Based on the existing theoretical knowledge, how to fully apply modern apprenticeship to the English teaching of preschool education major in higher vocational colleges is of great importance, mainly including the following aspects.

\section{1) The Role of Enterprises}

In the English teaching of preschool education major in higher vocational colleges, the role of enterprises is also important. With the fully application of modern apprenticeship and the support of schools and enterprises, practice and 
theoretical knowledge can be perfectly combined and an integrated talent training model will be formed. Besides, as one of the makers of teaching objectives, enterprises should participate more in all aspects of student cultivation, such as employment and training. Schools and enterprises should have relative authority in various aspects, so as to be mutually restrained and promote in-depth cooperation with each other. For example, teachers can provide more learning opportunities for students in internship through online teaching platform, while English practical teachers of enterprises can give lessons in school, so that good cooperation between schools and enterprises that modern apprenticeship requires can be realized [5].

2) Schools and Enterprises Form Teaching Staff Together

At present, the English teaching of preschool education major in higher vocational colleges requires teachers to have corresponding knowledge and practical abilities, but in reality, teachers are good at the explanation of theoretical knowledge and lack of practical ability in various aspects. Therefore, we need to give full play to the role of modern apprenticeship, strengthen the cooperation between schools and enterprises, and build a good teaching staff. Clear requirements should be made for teachers' teaching objectives and other aspects. The latest teaching ideas should be introduced to the class and the scope of knowledge be expanded, so as to achieve reasonable allocation of educational and practical resources.

\section{3) Ensuring Talent Quality with Modern Apprenticeship}

Nowadays, the quality of English teaching of preschool education major is uneven. Many aspects are to be improved. Therefore, exploring how to ensure the quality of talents on the basis of modern apprenticeship is the key and difficult issue at present. The students under the modern apprenticeship system join the enterprises from their own initiative, which means that we should give full consideration to the students' personal wishes at the same time in defining the teaching objectives of the schools and enterprises. Besides, after students practice in enterprises, the enterprises must ensure that students have sufficient time to study. On the basis of the above, the teachers of the higher vocational colleges and the teachers of the enterprises must communicate actively. For example, the English teachers of preschool education major can take the task from the manager responsible for the export as homework, so as to get closer to the job, and provide real cases, to make students feel that learning is useful. Moreover, the effectiveness of learning will be improved.

At the same time, under the modern apprenticeship system, the students' learning time and environment are restricted, which requires us to make full use of network resources and realize the perfect combination of online and offline teaching through the network platform. At the same time, we are actively exploring new development models based on the implementation of modern apprenticeship. For example, we require outstanding full-time students to provide certain guidance to students participating in modern apprenticeship and achieve a one-to-one development model. The learning environment of school will be improved and good learning results will be achieved. On this basis, it can also enable students to fully recognize the needs of society and lay a solid foundation for the future. At present, some of the preschool education departments in higher vocational colleges have adopted this "students guiding" system in English teaching, especially in the teaching of spoken English. Both apprenticeship students and full-time students have shown good results.

\section{SUMMARY}

Apprenticeship education mode in colleges and universities is an important mode of current education and training. The main purpose of introducing modern apprenticeship in China is to promote the students in higher vocational colleges to meet the requirements for talents of society and to meet the needs of enterprises. Therefore, it is necessary to integrate the professional knowledge and skills and other content of enterprises into the curriculum, so that students can enhance their sense of identity and belonging to the enterprises. This thesis explores the application of modern apprenticeship in English teaching of preschool education major in higher vocational colleges, and has a certain reference for the current English teaching of preschool education major in higher vocational colleges.

\section{REFERENCES}

[1] J. Guan, "What kind of enterprises should be selected for modern apprenticeship. China Education Daily”, 2015, in press

[2] J. Y. Chen, "Reflections on the Reform of Public Fundamental Courses in Higher Vocational Colleges under Modern Apprenticeship”, Journal of Nantong Vocational University, 2015

[3] L. Li, "Study and Practice of English Teaching in Vocational and Technical Colleges under the Mode of Modern Apprenticeship”, English on Campus, 2017

[4] Z. M. Xu, "Research on the School-based Curriculum Reform under English Apprenticeship in Higher Vocational Education”, Time Education, 2016

[5] Y. He, "English Teaching Practice in Secondary Vocational School Based on Modern Apprenticeship”, WENLIDAOHANG, 2017 